\title{
MISCELLANEA
}

\section{Occupational Mortality in Scotland}

\section{S. L. MORRISON}

\section{From the Social Medicine Research Unit of the Medical Research Council, London Hospital}

(RECEIVED FOR PUBLICATION FEBRUARY 11, 1957)

The Registrar-General for Scotland has recently published (Registrar-General for Scotland, 1956) his analysis of the deaths in Scotland from 1949 to 1953 in relation to the occupational distribution found in that country at the 1951 Census. This note focuses attention on two subjects in his Report, coronary heart disease and cancer of the respiratory system.

As the population concerned is relatively small $(1,795,273$ males aged 15 and over), occupations have been grouped in the Report in order to provide adequate numbers of deaths from the specific causes given. Some of these groupings bring together men working in very different conditions (e.g., " other water transport workers" includes firemen, greasers, pursers, stewards, bargemen, lock-keepers), and such groups have been excluded from consideration here.

The Report gives standardized mortality ratios (S.M.R.) for males aged 15 and over and aged 15 to 64 years for the following causes of death:-All tuberculosis; malignant neoplasms-total, and of the respiratory system; vascular lesions affecting the central nervous system; coronary heart disease; myocardial degeneration, etc.; bronchitis and pneumonia; accidental death. Only the S.M.R. at ages 15 to 64 years is considered here as the reliability of information both about a man's last job and his cause of death probably diminishes after the age of 65 . Unfortunately, the actual numbers of deaths from particular causes are not given for this age range, only the total number at ages 15 and over. The numbers of deaths in the required range have, however, been estimated and, in general, only occupations with S.M.R.s based on 50 or more deaths are discussed in this note. Where the number of deaths is possibly a little less than 50, the S.M.R. is printed in italics.

\section{Definitions}

Classification of Occupations.--The classification used is the official publication of H.M. Stationery Office (General Register office, 1951). The code numbers used are those given in that publication.

Standardized Mortality Ratio.-This is the ratio of actual to "expected" deaths, expressed as a percentage. The expected deaths are calculated by multiplying the age-specific death rates for all males by the number of men in the corresponding age groups in the particular occupation. Thus the ratio for all males is 100 . For example, an S.M.R. of 143 for coronary disease in clerks means that clerks have a death rate from coronary disease $43 \%$ higher than the rate for all males, when the effect of any difference in age structure between clerks and all males has been taken into account.

Registration of Death.-When a death is registered the informant is asked to give the last occupation of the deceased. This occupation may not, for various reasons, have been the job in which a man spent most of his working life, or the job recorded by him at the Census. Such differences are, naturally, more likely with men over 65 years of age.

\section{Coronary Heart Disease}

Occupations with an S.M.R. of 130 and above can be divided into two groups, those with no other S.M.R. (for the causes listed) of 130 and above, and those with other high S.M.R.s. Tables 1 and 2 list occupations according to these criteria.

\section{TABLE 1}

CORONARY DISEASE S.M.R. 130 AND ABOVE AND NO OTHER CAUSE 130 AND ABOVE

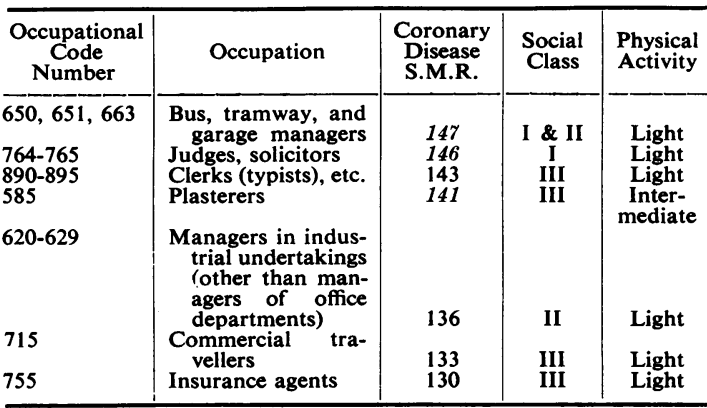

The classification of the occupation as "heavy", " light ", " intermediate", or " doubtful " is derived from a paper on mortality in relation to physical activity at work (Morris and Heady, 1953). All occupations in social classes I and II, except farmers, are regarded as "light".

Before discussing these tables, the obverse of the coin should be shown. Table 3, therefore, gives occupations with S.M.R.s of 70 or below.

This kind of evidence, based on crude occupational groupings and relatively small numbers of deaths, is unlikely to confirm or refute any particular hypothesis. However, it does give an opportunity to speculate and to look for clues that may be followed when the more detailed information for England and Wales becomes available. 
TABLE 2

CORONARY DISEASE S.M.R. 130 AND ABOVE AND OTHER (SPECIFIED) CAUSES 130 AND ABOVE

\begin{tabular}{|c|c|c|c|c|c|c|}
\hline \multirow{2}{*}{$\begin{array}{l}\text { Occupational } \\
\text { Code Number }\end{array}$} & \multirow{2}{*}{ Occupation } & \multicolumn{3}{|c|}{ S.M.R. } & \multirow{2}{*}{$\begin{array}{l}\text { Social } \\
\text { Class }\end{array}$} & \multirow{2}{*}{$\begin{array}{l}\text { Physical } \\
\text { Activity }\end{array}$} \\
\hline & & $\begin{array}{l}\text { Coronary } \\
\text { Disease }\end{array}$ & Other Causes & & & \\
\hline $\begin{array}{l}750-754,756-759 \\
766-769\end{array}$ & $\begin{array}{l}\text { Company directors, stockbrokers, etc. } \\
\text { Physicians and surgeons }\end{array}$ & $\begin{array}{l}196 \\
158\end{array}$ & $\begin{array}{l}\text { Vascular lesions of the C.N.S. } \\
\text { Vascular lesions of the C.N.S. } \\
\text { Accidental death }\end{array}$ & $\begin{array}{l}187 \\
183 \\
139\end{array}$ & $1 \underset{\text { I II }}{\&}$ & $\begin{array}{l}\text { Light } \\
\text { Light }\end{array}$ \\
\hline $610-611$ & $\begin{array}{l}\text { Civil Service, administrative and } \\
\text { executive classes }\end{array}$ & 154 & Vascular lesions of the C.N.S. & 187 & I \& II & Light \\
\hline $\begin{array}{l}830-831 \\
710-714,720-729\end{array}$ & $\begin{array}{l}\text { Police } \\
\text { Proprietors and managers in com- } \\
\text { merce, finance, and insurance }\end{array}$ & $\begin{array}{l}147 \\
141\end{array}$ & $\begin{array}{l}\text { Vascular lesions of the C.N.S. } \\
\text { Vascular lesions of the C.N.S. }\end{array}$ & $\begin{array}{l}187 \\
131\end{array}$ & $\begin{array}{l}\text { III } \\
\text { II }\end{array}$ & $\begin{array}{l}\text { Light } \\
\text { Light }\end{array}$ \\
\hline $380-389$ & Garment workers $\quad--\infty--$ & $-\overline{143}{ }^{-}$ & $\overline{\text { Tuberculosis }}-\overline{-}$ & 238 & III \& IV & Light \\
\hline
\end{tabular}

TABLE 3

CORONARY DISEASE S.M.R. 70 OR BELOW

\begin{tabular}{l|l|c|c|c}
\hline $\begin{array}{c}\text { Occupational } \\
\text { Code } \\
\text { Number }\end{array}$ & Occupation & $\begin{array}{c}\text { Coronary } \\
\text { Disease } \\
\text { S.M.R. }\end{array}$ & $\begin{array}{c}\text { Social } \\
\text { Class }\end{array}$ & $\begin{array}{c}\text { Physical } \\
\text { Activity }\end{array}$ \\
\hdashline $\begin{array}{c}030 \\
010,011,018 \\
020\end{array}$ & Foresters & 44 & III & Heavy \\
$\begin{array}{l}\text { 019, 021, 029 } \\
050-059\end{array}$ & $\begin{array}{l}\text { Farmers } \\
\text { Farm workers, etc. } \\
\text { Workers in mines, } \\
\text { quarries (not } \\
\text { coal-mining) }\end{array}$ & 55 & IV \& V & $\begin{array}{c}\text { Inter- } \\
\text { mediate } \\
\text { Heavy }\end{array}$ \\
\hline
\end{tabular}

Current hypotheses about the cause of coronary disease include three (Morris, 1956) to which these data may be related: that physical activity at work is protective; that excess fat in the diet is harmful; that nervous strain is harmful. One fact is known, namely, the excess mortality in social classes I and II. This was first shown in the occupational mortality figures for 1930-32 (Registrar-General, 1938) and is again clearly demonstrated in this Report. This fits all three hypotheses, since men in these classes have light occupations (except farmers whose S.M.R. is 49), their diet is probably richer than that of the other classes (Ministry of Agriculture, Fisheries, and Food, 1956), and they are often considered to be subject to more nervous strain. When all these factors are present, there may be other results in addition to increased coronary disease mortality. For instance, of the men in social class III occupations with high coronary disease S.M.R.s, 86\% appear in Table 1 and $14 \%$ in Table 2 ; for social class I and II occupations, $27 \%$ are in Table 1 and $73 \%$ in Table 2. Thus a high death rate from coronary disease in class I and II occupations tends to be associated with a high death rate from vascular lesions of the central nervous system, while in class III (with the exception of policemen) there is no such association.

Physical Activity.-All occupations, except plasterers, in Tables 1 and 2 are " light"; in contrast, none in Table 3 are "light". To go any further with this hypothesis, more detail about occupations and their death rates is necessary. The kind of analysis that was done on the occupational mortality data for England and Wales in 1930-32 (Morris, Heady, Raffle, Roberts, and Parks, 1953) must await publication of the full figures for England and Wales.

Diet.-The only occupations exposed to the occupa- tional hazards of eating larger quantities of dairy fats than average are farmers and farm workers. But excessive fat may only be harmful to men in "light " occupations and an interesting point arises from the presence of garment workers in Table 2. This group has the highest S.M.R. for tuberculosis (238) and one can speculate on the possibility of an association between a light occupation with an excess of tuberculosis which convalescent patients may pursue, on a diet rich in milk and butter-fat, and a high death rate from coronary disease. Similar occupations give the following results:-

\begin{tabular}{l|c|c|c}
\hline $\begin{array}{c}\text { Occupational } \\
\text { Code } \\
\text { Number }\end{array}$ & Occupation & \multicolumn{2}{|c|}{ S.M.R. for } \\
\cline { 2 - 4 } & Tuberculosis & $\begin{array}{c}\text { Coronary } \\
\text { Disease }\end{array}$ \\
\cline { 2 - 4 } $360-369$ & $\begin{array}{c}\text { Boot and shoe makers } \\
\text { Draughtsmen }\end{array}$ & 152 & 109 \\
\hline
\end{tabular}

" Nervous Strain ".-The occurrence of both " strain" and a richer diet in the same occupations has already been mentioned. Occupations in social classes I and II which have S.M.R.s below 130 (Table 4) may throw some light on the connexion of these two factors with coronary mortality.

TABLE 4

OCCUPATIONS IN SOCIAL CLASSES I AND II WITH CORONARY DISEASE S.M.R. BELOW 130*

\begin{tabular}{l|l|c}
\hline \multicolumn{1}{c|}{$\begin{array}{c}\text { Occupational } \\
\text { Code Number }\end{array}$} & \multicolumn{1}{|c}{ Occupation } & $\begin{array}{c}\text { Coronary } \\
\text { Disease } \\
\text { S.M.R. }\end{array}$ \\
\hline $786-794$ & $\begin{array}{l}\text { Professional engineers, surveyors, } \\
\text { etc. } \\
\text { 760-763 } \\
\text { Linisters of religion } \\
\text { Local authority officials, managers } \\
\text { of commercial and industrial } \\
\text { office departments } \\
\text { Teachers }\end{array}$ & 129 \\
780,785 & $\begin{array}{r}100 \\
90\end{array}$ \\
\hline
\end{tabular}

^Farmers are not included as they are not " light " workers

Both teachers and ministers of religion had high coronary disease S.M.R.s in England and Wales in 1930-32 (Registrar-General, 1938). Both occupations still appear to have plenty of "strain ", but have they not fallen behind the other professions in standards of living since 1932 ?

\section{Cancer of the Respiratory System}

There are good reasons for looking closely at the occupational data on lung cancer. Hueper (1956) has 
reviewed the epidemiology of lung cancer and he quotes the many industries where a specific risk of developing this disease has been found. Examples include nickel refining (in Clydach, South Wales, and Norway), chromate production, the production of coal gas, the manufacture of asbestos, and of arsenical sheep dip. In addition, however, suggestions have been made that dangers exist in other industries. Wynder and Graham (1951) suggested that "hot metal" workers and painters may be exposed to increased risk. A later study in the United States (Breslow, Hoaglin, Rasmussen, and Abrams, 1954) also found an association between exposure to metallic particles and fumes and lung cancer. In the United Kingdom, however, Doll (1953) found no such association.

Table 5 lists occupations with respiratory cancer S.M.R.s of 130 and above.

TABLE 5

MALIGNANT NEOPLASM OF RESPIRATORY SYSTEM S.M.R. 130 AND ABOVE

\begin{tabular}{l|l|c}
\hline \multicolumn{1}{c|}{$\begin{array}{c}\text { Occupational } \\
\text { Code Number }\end{array}$} & \multicolumn{1}{|c}{ Occupation } & S.M.R. \\
\cline { 1 - 2 } $160-164$ & $\begin{array}{l}\text { Platers, riveters, and shipwrights } \\
\text { Electrical apparatus makers and } \\
\text { fitters and electricians }\end{array}$ & 183 \\
131,132 & $\begin{array}{l}\text { Moulders } \\
\text { Masons and stone cutters }\end{array}$ & 170 \\
$1399-138$ & Foundry labourers, etc. & 162 \\
681 & Dock labourers & 161 \\
912 & Crane drivers & 157 \\
$600-609$ & Painters and decorators & 150 \\
\hline
\end{tabular}

Few occupations had an S.M.R. below 70; men in open-air occupations made up $80 \%$ of these (Table 6). The majority of such men are probably working in rural areas.

TABLE 6

MALIGNANT NEOPLASM OF RESPIRATORY SYSTEM S.M.R. 70 OR LESS

\begin{tabular}{|c|c|c|}
\hline $\begin{array}{l}\text { Occupational } \\
\text { Code Number }\end{array}$ & Occupation & S.M.R. \\
\hline $\begin{array}{l}019,021,029 \\
010,011,018,020 \\
110-119\end{array}$ & $\begin{array}{l}\text { Farm workers, etc. } \\
\text { Farmers, etc. } \\
\text { Foremen and overlookers in metal }\end{array}$ & $\begin{array}{l}25 \\
27 \\
54\end{array}$ \\
\hline $\begin{array}{l}013-015 \\
620-629\end{array}$ & $\begin{array}{l}\text { Market and other gardeners } \\
\text { Managers in industrial undertakings } \\
\text { (other than managers of office } \\
\text { departments) }\end{array}$ & $\begin{array}{l}56 \\
69\end{array}$ \\
\hline
\end{tabular}

Of the eight occupational groups with high S.M.R.s, five seem to fit Wynder and Graham's suggestions: painters and decorators and the four groups associated with "hot metal" working-platers and riveters, moulders, foundry labourers, and some crane drivers (not all crane drivers, of course, work in metal industries). It is interesting that one of the specific occupations suspected in the United States recently (Breslow and others, 1954) was "electric bridge crane operatorsmetal industry ".

In 1930-32 (Registrar-General, 1938) the occupation with the highest S.M.R. for lung cancer was " skilled workers in gas works" with 367 . Fourth and fifth highest respectively were " metal moulders and casters" 193 , and "iron foundry furnacemen and labourers"
188. Gas workers have since been shown to suffer a real excess mortality (Doll, 1952), so it may well be that "hot metal" workers deserve a comprehensive investigation.

Two of the occupational groups in Tables 5 and 6 need special care in the interpretation of their S.M.R.s. These are platers, riveters, and shipwrights who have a high S.M.R. for every cause, and foremen and overlookers in metal manufacturing with low ratios for every cause. In such cases, there may have been errors in the population. For example, when foremen die, their job may not be given in sufficient detail and the death may be attributed to other occupational groups in metal manufacture. Thus foremen would appear to have low ratios while those in the other groups may be slightly inflated. (The numbers of foremen are small in relation to other workers, so errors are not likely to raise other ratios significantly.) This kind of error does not seem so likely in the case of platers, riveters, and shipwrights, and their high S.M.R.s may reflect bad conditions of work in shipyards, including such adverse effects as returning to work too soon after illness.

\section{Occupational Selection}

One further point of general interest in the study of occupational death rates might be mentioned. This is the possibility that high rates for a particular disease in any occupation may be due to men with the disease selecting a suitable occupation, or of men with generally poor physique selecting certain light occupations. This factor is clearly shown by the S.M.R.s for " not gainfully employed" males between the ages of 15 and 64 . This group has low ratios for all causes except tuberculosis (220), myocardial degeneration, etc. (200), and bronchitis and pneumonia (175). It is not likely that because men are unemployed they die from these particular diseases, but that they are unemployed because they suffer from chronic conditions such as tuberculosis or bronchitis. The type of recruit entering any particular industry must, therefore, always be taken into account.

There are many other observations to be made on this material from Scotland and many facts of interest to all concerned with occupational health and disease.

I am grateful to colleagues in the Social Medicine Research Unit for their advice.

\section{REFERENCES}

Breslow, L., Hoaglin, L., Rasmussen, G., and Abrams, H. K. (1954). Amer. J. publ. Hith, 44, 171.

Doll, R. (1952). British Journal of Industrial Medicine, 9, 180.

General Register Office (1951). Classification of Occupations 1950. H.M.S.O., London.

Hueper, W. C. (1956). A Quest into the Environmental Causes of Cancer of the Lung. Public Health Monograph No. 36, Washington, D.C

Ministry of Agriculture, Fisheries, and Food (1956). Domestic Food Consumption and Expenditure: 1954. Annual Report of the National Food Survey Committee. H.M.S.O. London.

Morris, J. N. (1956). British Journal of Industrial Medicine, 13, 287. -, and Heady, J. A. (1953). Ibid., 10, 245.

, Raffle, P. A. B., Roberts, C. G., and Parks, J. W. (1953). Lancet, 2, $1053,1111$.

Registrar-General (1938). Decennial Supplement, England and Wales, 1931. Part IIA, Occupational Mortality, 1930-32. H.M.S.O., London.

Registrar-General for Scotland (1956). Annual Report 1955, No. 101. Appendix IX: Occupational Mortality, p. 75. H.M.S.O., Edinburgh.

Wynder, E. L., and Graham, E. A. (1951). Arch. industr. Hyg., 4, 221. 